\title{
South-South Cooperation in Education and Development: The ¡Yo, Sí Puedo! Literacy Method
}

\author{
Thomas Muhr \\ Address for correspondence: University of Nottingham, School of Education, Jubilee \\ Campus, Wollaton Road, Nottingham NG8 1BB, United Kingdom \\ Email: t.muhr2@gmail.com
}

\begin{abstract}
This article addresses two tendencies within the international education and South-South cooperation literatures: the omission of the Bolivarian Alliance for the Peoples of Our America-Peoples' Trade Agreement (ALBA-TCP) from discussions of South-South cooperation generally, and of the ALBATCP promoted ¡Yo, Sí Puedo! literacy method in particular. Central features of ¡Yo, Sí Puedo! are discussed, while the case of ¡Yo, Sí Puedo! in Nicaragua illustrates the main argument developed: $¡$ Yo, Sí Puedo! should not be regarded as 'best practice transfer' but as integral to South-South cooperation as Third World emancipation and transformation towards a socially just and democratic world order.
\end{abstract}

\section{Introduction}

Two distinct though interrelated tendencies within the Anglophone international and comparative education, adult and lifelong education, and South-South cooperation literatures can be observed: first, while formations such as 'BRICS' (Brazil, Russia, India, China, South Africa) and individual members thereof receive considerable attention, there is a marked silence about South-South cooperation promoted by the Bolivarian Alliance for the Peoples of Our America-Peoples' Trade Agreement (Alianza Bolivariana para los Pueblos de Nuestra América-Tratado de Comercio de los Pueblos, ALBA-TCP). Second, state-promoted mass adult literacy campaigns, a cornerstone of international and adult and non-formal education research at times of national liberation and decolonisation struggles in the 20th century, have virtually disappeared from scholarly and political attention post-1989. This would not be of greater relevance had two and a half decades of the hegemonisation of the "education for all' discourse, the 'Millennium Development Goals', neoliberal public-private partnerships (such as the 'Global Campaign for Education') and civil societal initiatives (especially the 'Global Partnership for Education'), brought about significant improvements in access to basic education. However, an estimated 57 million children are still excluded from formal education and 774 million adults classified as illiterate (UNESCO, 2014a). In this context the current discussions of the 'post-2015' development agenda, once more dominated by the governments, institutions and organisations of the global core, are followed critically from the periphery while counter-hegemonic initiatives are being developed (Carbonnier et al., 
2014, Enns, 2014, Hickling-Hudson et al., 2012, King, 2014, McGrath, 2014, Muhr, 2008, Muhr, 2010a and Muhr, 2013c). It is therefore surprising that the ALBA-TCP promoted $;$ Yo, Sí Puedo! $!^{1}$ literacy method, as the potentially most significant expression of global South-South cooperation in education in the first decade of the 21 st century, has received only marginal attention by academia in 'the North'.

This article addresses this absence, thereby adding to the scant literature on SouthSouth cooperation in education in the 21 st century. A brief outline of the notion of hegemony in conjunction with a historical sketch of South-South cooperation will be followed by a discussion of the decade-long protagonism of Cuban developmental internationalism in education and the more recent and growing role of Venezuela's Bolivarian revolution in reclaiming education at all levels as a free-of-charge public good, fundamental right and state responsibility. These policies have become interand transnationalised via the ALBA-TCP, of which the ¡Yo, Sí Puedo! is representative of one dimension of this multi-dimensional South-South development cooperation project. After all, it is the ALBA-TCP founding members Cuba and Venezuela that jointly - and jointly only - have the material, human and knowledge capabilities to promote a literacy campaign of, by now, global scope. While the Venezuelan petroleum resources provide a material base of the ALBA-TCP, 'Cuban socialism', as Helen Yaffe states, 'has been fundamental to inspiring and shaping' the initiative (Yaffe, 2013, p. 101). The case of ¡Yo, Sí Puedo! in Nicaragua illustrates the main argument of the article: that ¡Yo, Sí Puedo! should not be regarded as 'best practice transfer' among developing countries, but as integral to South-South cooperation as a collective counter-hegemonic process of Third World liberation and emancipation for structural transformation towards a socially just and democratic world order. $^{2}$

\section{Global counter-hegemony and South-South cooperation: Cuba, Venezuela, and the ALBA-TCP education cooperation}

Hegemony in this article refers to the supremacy of a social group, which manifests itself in economic, intellectual, political and moral leadership, to which the subalterns give their active consent, while coercion is used only exceptionally as a disciplinary

\footnotetext{
${ }^{1}$ Commonly, including the official discourse(s), ‘¡Yo, Sí Puedo!' is translated as 'Yes, I Can!'. I find this translation imprecise and have in previous work proposed I can do it!, as 'sí' in this context does not mean 'yes' but is used in an emphatic-affirmative way. Literally, '¡Yo, Sí Puedo!' would have to be translated as 'I Do Can!' (incorrect), by adding 'indeed' (I Can Indeed!) or by stressing the verb when speaking. Alternatively, perhaps the best translation is 'Sure I Can!' (UNESCO, 2014b). For purposes of consistency, the Castilian original will be used throughout this article. Translations from Castilian are the author's.

${ }^{2}$ As stated, this article advances a critique of existing literature in the fields of international and comparative education, adult and lifelong education, and South-South cooperation more generally. The empirical research upon which the discussion is based forms part of a larger socio-spatial ethnographic study of the construction of the ALBA-TCP, drawing from Michael Burawoy's reflexive science model and extended case method, as well as George Marcus' multi-sited ethnography. Seventeen months of fieldwork in different places at multiple scales (local, national, regional) in Brazil, El Salvador, Nicaragua and Venezuela have been conducted since 2005. Research in Nicaragua was conducted in 2006 (two weeks) and 2009 (four weeks), involving participant observation and field notes, 31 recorded interviews, and document and critical discourse analysis.
} 
measure (Gramsci, 1971). The consensual element in hegemony, i.e. the 'acceptance by the ruled of a conception of the world that belongs to the rulers', which appears as 'common sense', mystifies the power relations upon which the order rests (Fiori cited in Carnoy, 1984, p. 68). Counter-hegemony thus requires offering 'new understandings and practices capable of replacing the dominant ones' (Santos and Rodríguez-Garavito, 2005, p. 18) whilst 'building up the sociopolitical base for change through the creation of new historic blocs' (Cox, 1996, p. 140). On this basis I have theorised the ALBA-TCP as a counter-hegemonic project that seeks the construction of socialism at and across different geographical scales (including the body, the local, national, regional, global) through the dialectic between the 'state-inrevolution' and the 'organised society': the former denotes the emancipatory activation of state power, that is, the state-promoted organisation of the popular classes for the reconfiguration of the bourgeois-colonial state. The latter, as a counterhegemonic concept antithetical to liberal-bourgeois 'civil society', challenges the historical association of civil society with liberal individualism and a capitalist market society and means popular, mass-based organisation and the collective exercise of popular power through councils and movements as manifestations of non-capitalist social relations (Muhr, 2008, Muhr, 2010a, Muhr, 2010b, Muhr, 2012 and Muhr, 2013b).$^{3}$

Counter-hegemony is inherent to South-South cooperation as an idea, social practice and multi-dimensional set of processes, as it evolved during the post-World War II decades of political decolonisation: guided by structuralist and dependency theoretical thinking, Third World nations collectively sought greater economic independence from the centres of the bipolar 'Cold War' world order to overcome their perceived under-development. This process started with the 1955 Bandung Conference, followed by the foundation of the Non-aligned Movement (NAM) in Belgrade in 1961, where the Cuban government (following the successful revolution against the USA-supported Batista dictatorship on 1 January 1959) was the only Latin AmericanCaribbean state that participated as a member with a full delegation (Domínguez, 1989, p. 221) (I use 'Latin America-Caribbean' rather than 'Latin America and the Caribbean' to conceptually underscore the indivisibility of the geographical area, as expressed in Simón Bolívar's vision of 'Patria Grande' (the Grand Motherland) and José Martís 'Nuestra América' (Our America)). In 1964, during the first session of the United Nations Conference on Trade and Development (UNCTAD), the Group of 77 (G-77) was founded, which today is composed of 134 developing nations, and whose critique of the unequal terms of trade led in 1974 to the UN Declaration on the Establishment of a New International Economic Order (NIEO). These counterhegemonic efforts peaked with the 1978 Buenos Aires Plan of Action for Promoting and Implementing Technical Cooperation among Developing Countries, signed by 138 governments.

\footnotetext{
${ }^{3}$ The schematic, analytical presentation of key aspects of the ALBA-TCP in this section is necessarily selective and serves the arguments developed in this article. For background readings on the historical evolution of the ALBA-TCP, including its construction in Nicaragua, see Lambie and Alzugaray Treto 2011, Muhr, 2008, Muhr, 2013a and Muhr, 2013c. The counter-posing of 'civil society' with 'organised society' constitutes a theoretical and structuralist critique of 'civil society', that is, the promotion of 'civil society organisations' and 'non-government organisations' as structurally integral to neoliberalisation and the privatization of state responsibilities, rather than empirical in the sense of a critique of abusive practices by individual organisations (such as with respect to dampening, misdirecting or co-opting social protest, see Choudry and Kapoor, 2013).
} 
Michelle Morais de Sá e Silva characterises these three decades of South-South cooperation as a phase of 'self-reliance and political strengthening' (1949-1979), followed by 'demobilization' (1980-1998) associated with the neoliberal counteroffensive from within the capitalist core countries in the context of the 'debt crisis' and structural adjustment policies (Sá e Silva, 2009). A third phase can be identified from 1999 on with the World Bank's creation of the Global Development Network (GDN) and the emergence of North-South-South triangular collaboration, in which international agencies and Northern governments act as 'brokers' for 'best practice transfer' (or 'policy transfer') among developing countries (Sá e Silva, 2009). The practice of 'best practice transfer' originates in business management and has been defined as a 'firm's replication of an internal practice that is performed in a superior way in some part of the organisation and is deemed superior to internal alternate practices and known alternatives outside the company'; in other words, it means the 'movement of knowledge within the organization' (Szulanski, 1996, p. 28). With the World Bank adopting its self-styled role as a global 'knowledge bank' in the late 1990s, it simultaneously assumed the role of a "monitor and lender of "best practices", with other organisations of global governance, including Transparency International and United Nations (UN) agencies, following suit: together with such donor conditionalities as efficiency and effectiveness (performance enhancement) and practices of benchmarking, ranking and scoring, best practice transfer has been considered to advance 'interstate competition, coercion and convergence' (SteinerKhamsi, 2007, p. 285-286). As a unidirectional transplant of development 'solutions' irrespective of social, cultural, political and economic differences, this accommodation or cooption and reconceptualisation of South-South cooperation as 'transfer' rather than 'collective process' undermines the 'organic, political and potentially innovative nature of South-South cooperation' (Jules and Sá e Silva, 2008, p. 58).

As Sá e Silva (2009, p. 47) equally points out, the advocacy of 'best practice transfer', however, has been accompanied by a reinvigoration, or reintensification, of SouthSouth cooperation as Third World emancipation and liberation in Latin AmericaCaribbean. Historical key moments in this were the Cuban revolution's launch of the Integral Health Programme for Central America and the Caribbean within the context of Hurricane Mitch in 1998, followed by the inauguration of the Latin American School of Medicine (Escuela Latinoamericana de Medicina, ELAM) and the International School of Physical Education and Sports (Escuela Internacional de Educación Físisca y Deporte, EIEFD) in 1999 and 2001, respectively (De Vos et al., 2007; Hickling-Hudson et al., 2012). ${ }^{4}$ Simultaneously, with Hugo Rafael Chávez Frías assuming the presidency of the Bolivarian Republic of Venezuela in 1999, the renewed promotion of the New International Economic Order became a declared objective (e.g. Chávez, 1998; Chávez, 2005; República Bolivariana de Venezuela, 2001, p. 155-158). Accordingly, in 2000, the Venezuelan government unilaterally extended the 1980 'San José Oil Accord' (formally the Economic Cooperation Program for Central American Countries) through which the governments of Mexico and Venezuela had committed themselves to supplying 11 Central American and Caribbean with 160,000 barrels of oil and derivatives per day under a concessional

\footnotetext{
${ }^{4}$ It is noteworthy that while the economic crisis following the collapse of the Soviet Union forced the Cuban government to reduce its humanist (altruistic) cooperation during the first half of the 1990, this commitment was, however, never abandoned (De Vos et al., 2007; Hickling-Hudson et al., 2012).
} 
financing scheme, at the time considered the 'first collaborative aid effort between an OPEC [Organisation of the Petroleum Exporting Countries] and non-OPEC country' within the rationale of South-South cooperation (Grayson, 1985, p. 394). The progressive extension of the San José Oil Accord throughout the first half of the 2000s produced Petrocaribe in 2005, which in 2014 is composed of 19 'Caribbean Basin' states. Concomitantly, the Cuba-Venezuela Integral Cooperation Agreement, signed in 2000, led to the establishment of the ALBA-TCP in 2004 as the first formalisation of South-South cooperation at the regional scale in the 21 st century. ${ }^{5}$

With overlapping membership, shared institutions and both governed by the SouthSouth cooperation principles of complementarity, solidarity and cooperation, established as such by the Group of 77 Charter of Algiers of 1967, Petrocaribe can be theorised as a sub-regional strategy in the production of the ALBA-TCP space (Muhr, 2008; Muhr, 2011). In the ALBA-TCP/Petrocaribe discourse, solidarity is defined as 'The commitment to mutual support and joint efforts to achieve sustainable and integral human development, and the appropriate care of countries' emergent needs, within the possibilities and in accordance with shared responsibilities'; complementarity as 'The commitment to identify and develop joint projects that permit the integration and/or synergies of the capacities in accordance with their [partners'] potentialities and interests'; and cooperation as 'strategic alliances of mutual benefit' (Muhr, 2010b, Table 1). On this basis, I propose to define SouthSouth cooperation as it has been 'upscaled' in Latin America-Caribbean (from the international to the regional) as: more horizontal (egalitarian and just, at times - but not necessarily - altruistic) diplomatic, trade, aid and investment relations and exchanges of mutual benefit and for national and collective self-reliance, selfdetermination and independence, to liberate the (semi-)periphery from the exploitative unequal terms of trade with the core while strengthening its political autonomy within the and imperialist global system. In contrast to North-South official development assistance, South-South cooperation is a multi-dimensional and more integral and holistic approach to development across such areas as agriculture, culture, economy, education, energy, environment, finance, food, health, infrastructure, knowledge, law, military, production, and the humanitarian (Mawdsley, 2012; Fiddian-Qasmiyeh, 2015).

Accordingly, the ALBA-TCP multiple development dimensions and their institutions operate in a mutually reinforcing fashion, comprising the cultural, education and knowledge, energy, the environmental, the financial, the legal, the military, the politico-ideological, production and trade, and the social-humanitarian (Muhr, 2008; Muhr, 2010a; Muhr, 2013a; Muhr, 2013b). This holistic approach to development also characterises the education sector, in which all levels and modalities of education are understood as complementary and equally important to individual and collective development, whereby free-of-charge education at all levels is reclaimed as a 'public

\footnotetext{
${ }^{5}$ In early 2015, the ALBA-TCP full members are: Antigua and Barbuda, Plurinational State of Bolivia, Republic of Cuba, Commonwealth of Dominica, Republic of Ecuador, Grenada, Republic of Nicaragua, St. Kitts and Nevis, Saint Lucia, Saint Vincent and the Grenadines, Bolivarian Republic of Venezuela. Petrocaribe is composed of: Antigua and Barbuda, Commonwealth of The Bahamas, Belice, Republic of Cuba, Commonwealth of Dominica, Republic of El Salvador, Grenada, Republic of Guatemala, Co-operative Republic of Guyana, Republic of Haiti, Republic of Honduras, Jamaica, Republic of Nicaragua, Dominican Republic, St. Kitts and Nevis, Saint Vincent and the Grenadines, St. Lucia, Republic of Suriname, Bolivarian Republic of Venezuela.
} 
social good, fundamental human right and undeniable duty of the state' (ALBA, 2009, Point 23). Literacy, therefore, is at the root of an inclusive education system, manifest in two 'Grand-National Projects' (proyectos grannacionales, GNPs) which, by drawing on Bolívar's 'Patria Grande', are bi-/multi-state counter-hegemonic responses to capitalist multi-/transnational education corporations: the 'GNP ALBAEducation' and the 'GNP Literacy and Post-Literacy'. The latter, inter alia by use of ¡Yo, Sí Puedo! and ¡Yo, Sí Puedo Seguir! (Sure I Can Continue!), pursues universal primary education and 'integral post-literacy', which conceptually includes secondary and university education 'for all throughout the entire life', whilst 'integral' means linking theory with practice (Muhr, 2010a). By late 2014, 3,815,092 people of all ages (meaning that no particular age group is targeted) are officially stated to have acquired basic literacy through ;Yo, Sí Puedo! associated literacy campaigns in the ALBA-TCP member territories, and 1,174,312 had completed post-literacy nonformal elementary education (ALBA-TCP, 2014a). To contextualise these figures, in 2013 the ALBA-TCP member states population totalled 62,327,000, excluding Cuba, where no literacy campaign is in operation due to the nation's freedom from illiteracy since 1961, after the successful campaign in the first two years of the Revolution (population figures drawn from UNESCO, 2014a). These numbers further mean that several ALBA-TCP members - Antigua and Barbuda, the Plurinational State of Bolivia, Republic of Nicaragua, Bolivarian Republic of Venezuela - have been declared illiteracy-free territories by UNESCO. While precise figures of the global impact of ;Yo, Sí Puedo! appear to be unobtainable, the Director of the Latin American and Caribbean Pedagogical Institute (Instituto Pedagógico Latinoamericano y Caribeño, IPLAC), César Torres Batista, has been cited (in Radio Nacional de Venezuela, 2014) stating that by late 2014 8,203,324 people had acquired literacy through ¡Yo, Sí Puedo! worldwide, and over one million had benefited from ¡Yo, Sí Puedo Seguir!.

Strategies to globalise ¡Yo, Sí Puedo! and ¡Yo, Sí Puedo Seguir! include cooperation with the Common Market of the South (MERCOSUR) (see MERCOSUR, 2014), the Community of Latin American and Caribbean States (Comunidad de Estados Latinoamericanos y Caribeños, CELAC) (see ALBA-TCP, 2014b), and the AfricaSouth America (ASA) forum, within which Venezuela co-chairs the Culture and Education working group jointly with Senegal (ASA, 2009a; ASA, 2009b). The ASA summits involve the 54 African states and the 12 member states of the Union of South American Nations (Unión de Naciones Suramericanas, UNASUR), of which Venezuela is a member but not Cuba. In this forum, the Venezuelan Mission Robinson International (Misión Robinson Internacional) is used as the medium to globalise ¡Yo, Sí Puedo! in collaboration with the UNASUR Working Group on Educational Integration (see ASA, 2009b). ¡ Yo, Sí Puedo!, however, as the Nicaraguan case underscores, is not only implemented inter-governmentally, but also transnationally through cooperation between the Cuban government and subnational government units (e.g. mayoralties) as well as with non-state actors, such as the Rural Landless Workers Movement in Brazil (Movimento dos Trabalhadores Rurais Sem Terra, MST). This strategy is anchored in Cuban developmental internationalism, which started as early as 1960 (the second year of the Revolution), in which interstate relations have always coexisted with transnational support to revolutionary movements (Domínguez, 1989). 
By 2010, according to the Cuban Permanent Ambassador to the UN, Cuba had implemented South-South cooperation programmes in 157 countries in Africa, Asia and Latin America-Caribbean (Núnez Mosquera, 2010). As in the ALBA-TCP, cooperation programmes are developed in accordance with the partner's needs and idosyncracies, are mostly free of charge and with no conditionalities attached. In some cases, depending on the partner's economic situation, the Cuban government has charged (variable) commercial rates for services, however, below world market prices, thus generating a 'win-win' relation characteristic of South-South cooperation (Domínguez, 1989; Erisman, 1991; Hickling-Hudson et al., 2012). With respect to education, Cuban internationalism has always had two dimensions: providing full studentships for study in Cuba (primary, secondary, tertiary), with the first students arriving from Angola in 1976, mainly for teacher training; and sending teachers abroad, whereby the first overseas education programme was implemented in the former Spanish colony of Equatorial Guinea in 1973 (Domínguez, 1989; Erisman, 1991; Hatzky, 2012). About 22,000 Cuban teachers worked abroad between 1973 and 1985 (Hickling-Hudson et al., 2012), and over 55,000 international students on full scholarships from 148 countries had graduated from Cuban secondary, vocational and tertiary education institutions by 2008 (Martínez Pérez, 2012). Technical cooperation has involved the provision of requested school infrastructure (buildings, classrooms), and overseas education has also involved the training of doctors, besides adult literacy and continuing education programmes. To these, such modalities as assistance with curriculum development, sector development and collaboration programmes (e.g. special education, early childhood education, sports and physical education), and training in university policy development and administration can be added (HicklingHudson et al., 2012).

With support from Cuban specialists and increasingly also Venezuelan advisors, ¡Yo, Sí Puedo! has been used across Latin America-Caribbean beyond the ALBA-TCP members, including in Argentina, Belize, Brazil, Colombia, Dominican Republic, El Salvador, Grenada, Guatemala, Haiti, Honduras, Jamaica, Mexico, Panama, Paraguay, Peru and Uruguay; in African countries, specifically Angola, Cape Verde, Guinea Bissau, Ethiopia, Mozambique, Namibia, Nigeria, and South Africa; in Asian contexts, especially Timor Leste; and in Australia, Canada, New Zealand, Spain and the USA - often at sub-national scales organised by state and non-state actors and with results recognised by UNESCO. In this process, as much as financial means permit, the method has been localised, that is, adapted to (at least) 14 different sociolinguistic contexts, including Aymara, Creole, English, Guarani, Portuguese,

Quechua, Swahili, Tetum, and braille (Artaraz, 2011; Boughton and Durnan, 2014a; Boughton and Durnan, 2014b; Boughton and Durnan, 2014a; Boughton and Durnan, 2014b; Muhr, 2008; Sanín, 2012; UNESCO, 2014b; Yaffe, 2013). The following section discusses key features of the method, before illustrating its role in social organisation and mobilisation in Nicaragua.

\section{The method}

¡Yo, Sí Puedo! was developed in the early 2000s by Leonela Relys Díaz at the aforementioned IPLAC, which belongs to the Cuban Ministry of Education, and 
builds upon Relys Díaz's experiences in the 1961 campaign and Cuban educators' development of a radio literacy method in the Republic of Haiti in the late 1990s (Boughton, 2010; EcuRed, 2014). Although ¡Yo, Sí Puedo! is often used synonymously with the associated literacy campaigns or programmes, strictly speaking the name denominates the alphanumeric method that makes use of audiovisual technology (for details of the pedagogical aspects, see EcuRed, 2014; Boughton, 2010; Boughton and Durnan, 2014a). In 2006, ¡Yo, Sí Puedo! was awarded the UNESCO King Sejong Literacy Prize (UNESCO, 2006b). Within the inter- and transnational cooperation frameworks, the Cuban government usually also provides advisors as well as TV sets, video players, teaching materials (video classes, primers), in some cases solar panels for energy generation in remote zones, general health checks including eyesight tests, and reading glasses. As stated, the method's localisation involves socio-cultural adaptation, mirrored in reference to anti-colonial and/or anti-imperialist liberation fighters. For example, in Venezuela the campaign is called Misión Robinson (Mission Robinson), in Uruguay En el País de Varela: Yo, Sí Puedo (In Varela's Country: Yo, Sí Puedo), and in Nicaragua Campaña Nacional de Alfabetización 'De Martí a Fidel' (National Literacy Campaign 'From Martí to Fidel'). Such 'politicisation', as some may view it, is less extraordinary than it might appear, as historically literacy campaigns have always contained 'a special cosmology of symbols, martyrs, and heroes' (Arnove and Graff, 1987, p. 2). Accordingly, while a 'literacy campaign' can be defined as 'a mass approach that seeks to make all adult men and women in a nation literate within a particular time frame', the notion of 'campaign' suggests urgency, combativeness and a 'spirit of expeditions or crusades' (Bhola, 1984, pp. 35, 196).

A UNESCO (2006a) study of early uses of ¡Yo, Sí Puedo! identified a number of shortcomings especially with respect to contextualisation and national coordination of its implementation (see Boughton and Durnan, 2014a, for discussion). While such issues have apparently been addressed, easily overlooked is that the principal objective of $;$ Yo, Sí Puedo! is to facilitate basic literacy acquisition within a short time. As literacy workers of the Nicaraguan Carlos Fonseca Amador Popular Education Association (Asociación de Educación Popular Carlos Fonseca Amador, henceforth 'Fonseca Amador Association') emphasised in personal communication, in contrast to traditional methods that require one year or longer to acquire literacy (which produces high drop-out), ¡Yo, Sí Puedo! facilitates literacy acquisition within 65 days of classes. ${ }^{6}$ It is vital, however, to clarify what 'being literate' actually may mean in this context. Historically, UNESCO defined a 'literate' person as someone 'who can with understanding both read and write a short simple statement on his [i.e. their] everyday life'. From 1978 on this rationale became superseded by the notion of functional literacy as having 'acquired the knowledge and skills in reading and writing which enable [a person] to engage effectively in all those activities in which literacy is normally assumed in his [i.e. their] culture or group' (UNESCO, 2000, p. 30). With respect to ¡Yo, Sí Puedo!, UNESCO applies the first of the two conceptions: as being 'able to write a legible letter in a defined format at the end of

\footnotetext{
${ }^{6}$ The Facilitator Manual used during the Nicaraguan campaign states 65 classes structured in three stages: 'introductory practice' (adiestramiento) (10 classes), 'teaching reading and writing' (enseñanza de la lectura y la escritura) (42 classes), 'consolidation' (11 classes + two classes for composition writing (redacción). Boughton and Durnan (2014b, p. 342) state a similar structure comprising 64 classes (stage one 7; stage two 45; stage three 12).
} 
the course' (UNESCO, 2006a, Point 7; also see Boughton and Durnan, 2014b). Subsequently, 'post-literacy' then relates to functional literacy, associated with daily socio-productive/economic activities and the notion of literacy as a 'continuous process' (Lind, 2008, p. 42) - a conception of literacy that has been accommodated in the ¡Yo, Sí Puedo! post-literacy programmes, leading to the establishment of a nonformal adult education system in the long run (Boughton, 2010). Accordingly, as in Cuba, where the literacy campaign was complemented by Seguimiento (Follow-Up) and La Batalla para el Sexto Grado (The Battle for the Sixth Grade) (Kozol, 1978), in Nicaragua post-literacy is provided through ¡Yo, Sí Puedo Seguir!, ¡Ya Sé Leer! (I Can Already Read!), El Maestro en Casa (The Teacher in the Home, via radio), and Educación Continua de Adultos (Continuing Adult Education). This structure prepares for basic and medium education (MINED, 2011), termed (as in Cuba five decades earlier) La Batalla por el Sexto y Noveno Grado (The Battle for the Sixth and Ninth Grade) (GRUN, 2012, Point 379; for further modalities of non-formal youth and adult education, see MINED, 2014).

Although Jules and Sá e Silva (2008, p. 57) and Sá e Silva (2009,pp. 52-55) recognise that $;$ Yo, Sí Puedo! engenders political cooperation, a stronger dissociation of their view of ¡Yo, Sí Puedo! as technical 'policy transfer' or 'best practice transfer' for 'lessons to share', and reference to 'Third World autonomy' merely being 'part of the discourse', is necessary. Otherwise, this would not only mean to erode the significance of the Cuban literacy campaign of 1960/61 as 'a moment of political and moral transformation' (Kozol, 1978, p. 349), but also to subvert the history of Cuban internationalism and ignore that the ALBA-TCP is first and foremost a political project-as all foreign policy and cooperation schemes are, although they may serve different interest groups, classes or class fractions. Even though the political purpose of ¡Yo, Sí Puedo! is rarely made explicit, both UNESCO (2006a, Points 5, 25-27) and the available case studies highlight the social mobilisation and emancipatory and empowering element of the method (Artaraz, 2011; Leal, 2013; Boughton and Durnan, 2014a; Boughton and Durnan, 2014b; Muhr, 2008; Sanín, 2012; Steele, 2008). As the Nicaraguan campaign website explicates, ¡YY, Sí Puedo!...

...does not limit itself to learning to read and to write only. It goes much further. It pursues a conscientising and transformatory literacy, besides schooling...It has as its fundamental objective the active insertion of the participants in the social, economic and political activities of the community and the country in which they live (MINED Juventud Sandinista, 2014).

While large-scale literacy campaigns have existed since the sixteenth century and 'are not the exclusive province of any particular ideology' (Bhola, 1984, Preface), in the twentieth century they became increasingly associated with socialist revolution and the idea and practices of Freirean transformative education (Arnove and Graff, 1987; Bhola, 1984; Boughton, 2013; Kane, 2001; Lind, 2008; McLaren, 2000; Motta and Cole, 2013a). Also referred to as 'humanistic approach to questions of development', liberation pedagogy is intrinsic to counter-hegemony (Fägerlind and Saha, 1989, pp. 25-26). As a process of conscientization, that is, self-reflected awareness ('critical consciousness') through 'critical dialogue', popular education seeks to empower the marginalised and dispossessed to transform 'the structure of oppression' (capitalism, that is) (Freire, 1996[1970], p. 55). Literacy as a liberating, dialectical process of 
continuous acting and reflecting ('praxis') thus pursues the generation of 'popular power' through 'the (re) construction of sociabilities, political subjectivities and collectivities' (Motta and Cole, 2013a, p. 9).

In Latin America-Caribbean today, such practices of popular education are once again - as a product of decades of resistance to neoliberalisation - ubiquitous, and involve not only literacy but also other educational levels and modalities, including tertiary education (Duffy, 2014; Muhr and Verger, 2006; Lopes Cardozo and Strauss, 2013; also see the following collections: Griffiths and Millei, 2013a; Griffiths and Millei, 2013b; Motta and Cole, 2013b). Promoted by states and local, community actors, popular education contributes to the construction of a 'transnational organised society' through a politics of place, space and scale (Muhr, 2010a; Muhr, 2013a; Muhr, 2013c). This, as a consciousness creating process, is diametrically opposed to 'participation' in the neoliberal regime for 'efficiency', 'transparency' and 'accountability' as 'core elements of the aid effectiveness paradigm', through the inclusion of 'non-government' and 'civil society' organisations 'to ensure better developmental outcomes' (whereby development is understood as a technocratic exercise) (Mawdsley, 2012, pp. 101-107). The following case study of the appropriation of $;$ Yo, Sí Puedo! by the Nicaraguan people stands out for (at least) two reasons: first, historically, the Cuban Revolution already provided educational assistance to Nicaragua's Sandinista Revolution of the 1980s, led by the Sandinista National Liberation Front (Frente Sandinista de Liberación Nacional, FSLN) after toppling one of the longest-lasting USA supported dictatorships in the geographical area in 1979, Cuba's by then 'largest such commitment in the world' (Domínguez, 1989; Schwab and Sims, 1985). ${ }^{7}$ Second, methodologically, ¡ Yo, Sí Puedo! was initiated at the local scales from 2005 on in a context of structural crisis after 16 years of neoliberalisation, which in education was manifest, inter alia, in an official illiteracy rate of $20.1 \%$ (with alternative estimates ranging between 32 and 34\%) (Muhr, 2008; Muhr, 2013a).

\section{4. ¡Yo, Sí Puedo! in Nicaragua: (re) constructing the organised society}

As in Cuba twenty years earlier, the 1980/1981 Great National Literacy Crusade 'Heroes and Martyrs for the Liberation of Nicaragua' (Gran Cruzada Nacional de Alfabetización Héroes y Mártires por la Liberación de Nicaragua) was the first national project of the revolutionary government, laying the foundation for national reconstruction (Barndt, 1985; Arnove, 1986). By drawing from the Cuban experience, other literacy campaigns in Third World nations (Mozambique, Guinea Bissau, Cape Verde), and Freire's personal involvement, illiteracy was reduced from over 50\% to under $15 \%$ of the population of 10 years and older, for which the campaign earned the 1980 UNESCO Literacy Prize (Barndt, 1985; Arnove, 1986). By the late 1980s, the illiteracy rate had again risen to over $20 \%$, largely due to the so-called 'Contra War',

\footnotetext{
${ }^{7}$ By the mid-1980s, 5000 Cuban teachers had served in Nicaragua, working with 250,000 students (almost 10\% of the Nicaraguan population of 2.6 million at the time) (Domínguez, 1989, p. 177). Cuba's educational mission in Angola, in which approximately 10,000 Cubans were deployed as teachers and advisors between 1976 and 1991, has been stated as the largest educational commitment to date (Hatzky, 2012).
} 
for which the USA government was found guilty of terrorism against Nicaragua by the International Court of Justice (Graham-Brown, 1991; International Court of Justice, 1998).

Within the revolutionary context of mass mobilisation, out of a population of 2.4 million at the time, depending on source, 55,000-60,000 brigadistas (young people that made up the Popular Literacy Army) and 26,000-35,000 popular alphabetisers (mostly adult Popular Literacy Teachers) became involved in the literacy process through which 400,000-500,000 Nicaraguans acquired basic literacy (Council on Interracial Books for Children, 1986[1981]; Arnove, 1986). Organisationally, the campaign was structured into consultative councils that operated at the national territorial, zonal and regional scales, in which delegates of the mass organisations were brought together (farmers, teachers, state institutions, educational experts, students) (Arríen, 1990). In pursuit of functional literacy, the 'crusade' was followed up by an adult basic education programme that involved over 20,000 voluntary teachers and about 200,000 participants (Arnove, 1986). With the FSLN's defeat in the 1990s presidential election and consecutive neoliberal governments until 2006, the Nicaraguan socio-political landscape profoundly changed as a result of the individualisation of poverty and the related fatalism and hopelessness. ${ }^{8}$ As Vanden observed: 'What was once a nation mobilised and ready to take on almost any challenge that the US, its allies or quislings might hurl at it, had become as cowed and downtrodden as any in the Third World' (Vanden, 1999, p. 69). In this historical context, ¡Yo, Sí Puedo! - perhaps unintentionally - contributed to the reconstruction of the organised society.

In early 2005, the Fonseca Amador Association, which was formed by FSLN members post-1990, called on the international community for support to achieve the Millennium Development Goals with respect to literacy. As the only one to respond, the Cuban government provided the ¡Yo, Sí Puedo! method alongside six advisors and resources for 5000 'literacy points' (puntos de alfabetización) (TV sets, video players, sets of video classes, primers, facilitator guides). The following two years, $¡$ Yo, Sí Puedo! became implemented transnationally — that is, between the Cuban state, the Fonseca Amador Association and Nicaraguan municipal councils, especially those governed by the FSLN, whereby the Fonseca Amador Association's National Commission was responsible for technical and pedagogical coordination, training and evaluation, while the participating municipalities established Municipal Commissions for Literacy (Muhr, 2008). From 2008 on, with Nicaragua having joined the ALBATCP in January 2007 and the universalisation of ¡Yo, Sí Puedo! as the National Literacy Campaign 'From Martí to Fidel' (launched on 23 June 2007), 86 Cuban advisors and 61 Venezuelan brigadistas supported the literacy and post-literacy campaigns (MINED, 2009, p. 10) ${ }^{9}$, while the Fonseca Amador Foundation adapted the method to the linguistic and cultural realities of the nation (Creole English; the indigenous languages Miskito, Mayagna/Sumu, Garífuna; and Castilian braille). However, as the Final Report of the National Literacy Campaign 'From Martí to

\footnotetext{
${ }^{8}$ Between January 1997 and March 2000 I worked in educational institutions in Nicaragua, at different levels and in varying social environments. Since 2001, I have been researching aspects of Nicaraguan politics, development and education.

${ }^{9} \mathrm{Bi}$ - and multilateral support further included the Spanish Agency for International Cooperation and Development and UNESCO, amongst others (MINED, 2009, p. 11).
} 
Fidel' states, $¡$ Yo, Sí Puedo! was used to an extent of $64.31 \%$, while in the remaining $35.69 \%$ of the campaign a 'constructivist' mixed method (método mixto) found application in especially rural zones (MINED, 2009). ${ }^{10}$ With a total of 324,895 persons acquiring basic literacy between 2007 and 2009 (MINED, 2011), on 16 June 2009 , Nicaragua was declared illiteracy-free by a multi-institutional commission composed of scientists from the organisations and institutions concerned with education in the country, stating a remaining illiteracy rate of $4.73 \%$ (UNESCO et al., 2009). ${ }^{11}$ By 2011, according to the Ministry of Education, a total of 502,651 persons had become literate (which includes the 138,637 alphabetised by the Fonseca Amador Foundation during 2005/2006) (MINED, 2011), as illiteracy was further reduced to 3\% in 2011 (GRUN, 2012, Point 368). In 2013 13,519 literacy points actively involved 75,018 learners (GRUN, 2014).

For the purposes of this article, the most remarkable aspect of the campaign is the popular mobilisation that facilitated its success: between 2005 and 2007, the direct cooperation with the municipalities allowed the campaign to be run by approximately 5000 volunteers. Nicaraguans 'appropriating the ¡Yo, Sí Puedo!', as the Managua coordinator stated in 2006, meant the exclusive operation of the campaign by the Nicaraguan people: employees of the mayoralties, members of the FSLN community base structure, and individuals, including students from state universities that conducted survey studies. Commonly classes were held in the facilitators' or community leaders' own homes, and occasionally in community centres and nongovernment organisation and ecclesiastical premises. This was not only a 'democratic support structure' and expression of solidarity, as one informant argued, but also a necessity given the resource scarcity (Muhr, 2008). Subsequently, during the National Literacy Campaign 'From Martí to Fidel', 57,631 voluntary literacy workers were mobilised (50,531 under 35 years of age, $66 \%$ women, and $77 \%$ in rural zones), which represents about $1 \%$ of the total population of 5.74 million in $2009 ; 77 \%$ of the literacy classes were held in private homes, $18 \%$ in schools, the rest in churches, communal centres, prisons and other government and non-government localities (MINED, 2009, p. 19). Volunteers from all walks of life joined: individual teachers; popular and religious community leaders, especially from the direct democratic Citizen Power Council structure; students from state and private universities; youth organisations, such as the Federation of Secondary Students (Federación de Estudiantes de Secundaria, FES), the National Union of Students of Nicaragua (Unión Nacional de Estudiantes de Nicaragua, UNEN), and Sandinista Youth 19 July (Juventud Sandinista 19 de Julio); teacher unions; the FSLN base structure; municipal governments; state institutions (ministries, the army, the police); and private enterprises. From as early as 2006, graduation ceremonies were organised to celebrate the successes of the campaign in those barrios (working class quarters) that had been

\footnotetext{
${ }^{10}$ MINED describes this 'mixed method' as an active-participative approach that combines 'the psychosocial method, the method of the generative word, with analysis and synthesis' (2009, pp. 1314).

${ }^{11}$ The survey was based on a random sample of 12,538 persons of the 15-65-year age group in 22 municipalities (including Managua as the largest municipality), with a calculated sampling error of $1 \%$ and a level of confidence above $97 \%$. For further technical and methodological details, see UNESCO et al. (2009). Two weeks after the release of that report, on 30 June 2009, MINED released its own Final Report (MINED, 2009), which states a national illiteracy rate of $4.1 \%$. The report presents the data sets for all departments and municipalities.
} 
declared illiteracy free. These ceremonies, as UNESCO states with respect to ¡Yo, Sí Puedo! in Uruguay, support the collectivisation of the experience:

By means of the graduation ceremonies participants are able to take ownership of their achievements and recognise the influence that their new knowledge has had on their family and community. Rather than being a rigid and wholly private achievement, the community developed skills in an individual manner and transported the knowledge back to their families and communities (UNESCO, 2014b).

Even though individual participants do not necessarily become 'historical Subjects', that is, 'Subjects of the transformation' (Freire, 1996[1970], p. 108, 111, 141) within 8-10 weeks of ¡Yo, Sí Puedo! classes, the general popular mobilisation produces society - the organised society - in defiance of the liberal-capitalist ontology of individualism and 'neoliberal totalitarianism' (cf. Giroux, 2014). While Nicaragua, due to the nation's historical trajectory, may not be representative of all contexts in which ¡Yo, Sí Puedo! is deployed, there over 1.1 million people (of a total population of about six million in 2014) are annually mobilised in organised, collective solidarity action (rather than liberal individualistic charity) (GRUN, 2012, Point 9), not only in the literacy campaign but also in other state and ALBA-TCP promoted schemes related to reforestation, public health care and social inclusion of, for instance, street children. Therefore, the Cuban, and by extension, the ALBA-TCP literacy work, as Bob Boughton and Deborah Durnan state, 'deserves to be seen as a continuation of Freire's own global mission' (Boughton and Durnan, 2014a, p. 576).

\section{Conclusion and outlook}

Best practice transfer is the transfer of 'solutions' to development problems from one country of the South to another, implemented through a loan or grant from a Northern government or international organisation, especially the World Bank (SteinerKhamsi, 2007). Underlying to this instrumentalist neo-imperialist global governance practice is a problem-solving ideology that presents 'development' as simply a technical, objective intervention (Jules and Sá e Silva, 2008). Such transfer, however, as Jules and Sá e Silva state, 'includes voluntary and coercive processes', which contrasts with (South-South) cooperation as a purely 'voluntary process' (2008, p. 58). On this basis I have argued that ¡Yo, Sí Puedo! should be dissociated from 'best practice transfer' as it neither constitutes a unidirectional technical transplant, nor does its globalisation involve conditionalities and other forms of coercion.

Even if 8.2 million people have acquired literacy through the ¡Yo, Sí Puedo! associated literacy campaigns, as previously stated in Section 2, this may appear negligible in the face of 774 million illiterate adults worldwide (UNESCO, 2014a). The significance of ¡Yo, Sí Puedo!, and of the ALBA-TCP generally, however, is greater than quantitative achievements may suggest: it is a counter-hegemonic SouthSouth cooperation process among like-minded organised social and political (state) forces that epitomises the general deprivatisation and decommodification of basic utilities, thus contesting, inter alia, the 'new global governance of education' (Robertson et al., 2007, p. 63). The general omission of such South-South initiatives 
from the international education literature points to the larger issue at stake: as Griffiths and Millei state, 'while the question of socialism, and the idea of communism, for this century, receives growing treatment across the social sciences, we see limited attention to such questions in the Comparative and International Education (CIE) field' (Griffiths and Millei, 2013a, p. 164). It is precisely such real initiatives as the ALBA-TCP, constructed by protagonists of, in and from the South themselves, rather than mere 'civil societal consultation' and the (in)famous postmodern 'voices from below', that are in the vanguard of challenging another neoliberal millennium 'post-2015' global elite consensus - for a socially just and democratic world order.

\section{Acknowledgements}

I would like to thank two anonymous reviewers for their insightful and constructive comments. Fieldwork in Nicaragua in 2006 and 2009 was sponsored via UK Economic and Social Research Council (ESRC) doctoral and post-doctoral scholarships (PTA-030-2003-00417; PTA-026-27-1902).

\section{References}

ALBA, 2009. Declaración de Managua. Por la Unión Educativa del ALBA, Managua, 3 September. ALBA-TCP, 2014.

ALBA-PTA Management Report 2004-2014. 10 Years Consolidating Solidarity and Integration Among the Peoples of Our America, Executive Secretariat, http://albatcp.org/public/documents/decimo/English/Management_report.pdf (accessed 20.11.14.).

ALBA-TCP, 2014. I Reunión de los Organismos Regionales y Subregionales de Integración para elaborar Agenda Estratégica de Coordinación Regional en Materia Social de la CELAC, Executive Secretariat, Caracas, 10 June, http://albatcp.org/contenido/i-reunion-de-los-organismos-regionales-y-subregionales- deintegracion-para-elaborar-agenda (accessed 20.10.14.).

Arnove, R.F., 1986. Education and Revolution in Nicaragua. Praeger, New York.

Arnove, R.F., Graff, H.J., 1987. Introduction. In: Arnove, R.F., Graff, H.J. (Eds.), National Literacy Campaigns: Historical and Comparative Perspectives. New York, Springer, pp. 1-28.

Artaraz, K., 2011. New Latin American networks of solidarity? ALBA's contribution to Bolivia's national development plan. Global Social Policy 11 (1), 88-105.

Arríen, J.B., 1990. Nicaragua: Mobilizing the Local Community for Literacy and Post-literacy. UNESCO, Geneva. 
International Journal of Educational Development 43 (2015) 126-133, http://dx.doi.org/10.1016/j.ijedudev.2015.04.005

ASA (Africa-South America Summit), 2009. Declaration of Nueva Esparta, 2nd Africa-South America Summit, Isla de Margarita, 26/27 September.

ASA, 2009. Proposal of the Plan of Action of the 1st Bi-regional Meeting of the Working Group on Education and Cultural Affairs, 2nd Africa-South America Summit (ASA), Isla de Margarita, 26/27 September.

Barndt, D., 1985. Popular education. In: Walker, T.W. (Ed.), Nicaragua: The First Five Years. Praeger, New York, pp. 317-345.

Bhola, H.S., 1984. Campaigning for Literacy. Eight National Experiences of the Twentieth Century, With A Memorandum to Decision-makers. UNESCO, Paris.

Boughton, B., 2010. Back to the future? Timor-Leste, Cuba and the return of the mass literacy campaign. Lit. Numer. Stud. 18 (2), 58-74.

Boughton, B., 2013. Popular education and the 'party line'. Glob. Soc. Educ. 11 (2), 239-257.

Boughton, B., Durnan, D., 2014a. Cuba's yes, I can mass adult literacy campaign model in Timor-Leste and aboriginal Australia: a comparative study. Int. Rev. Educ. 60 (4), 559-580. doi:http://dx.doi.org/10.1007/s11159-014-9421-5.

Boughton, B., Durnan, D., 2014b. Cuba's Yo Sí Puedo. A global literacy movement? Postcolonial Directions Educ. 3 (2), 325-359.

Carbonnier, G., Carton, M., King, K., 2014. International education and development: histories, parallels, crossroads. Int. Dev. Policy 5.

Carnoy, M., 1984. The State And Political Theory. Princeton University Press, New Jersey.

Chávez, H.R., 1998. La Propuesta para Transformar a Venezuela: Una Revolución Democrática. Caracas.

Chávez, H.R., 2005. !No Demos Descanso A Nuestros Brazos, Ni Reposo A Nuestras Almas Hasta Salvar La Humanidad!, Speech At The 60th Un General Assembly. UN, New York.

Choudry, A., Kapoor, D., 2013. NGOization: Complicity, Contradictions And Prospects. Zed Books, London.

Council on Interracial Books for Children, 1986[1981]. Education for change: a report on the Nicaraguan literacy crusade, In: Rosset, P., Vandermeer, J. (Eds.), Nicaragua: Unfinished Revolution. The New Nicaragua Reader. New York, Grove, pp. 418-421.

Cox, R.W., 1996. Approaches To World Order. Cambridge, Cambridge University Press. 
De Vos, P., De Ceukelaire, W., Bonet, M., Van der Stuyft, P., 2007. Cuba's international cooperation in health: an overview. Int. J. Health Serv. 37 (4), 761-776.

Domínguez, J.L., 1989. To Make a World Safe for Revolution. Cuba's Foreign Policy. Harvard University Press, Cambridge, MA.

Duffy, M., 2014. Education, democracy and social change: Venezuela's education missions in theory and practice. J. Educ. Policy. doi:http://dx.doi.org/10.1080/ 02680939.2014.981868.

EcuRed, 2014. Programa cubano de alfabetización Yo Si Puedo, http://www.ecured. cu/index.php/Programa_cubano_de_alfabetizaci\%C3\%B3n_Yo_si_Puedo (accessed 23.10.14.).

Enns, C., 2014. Transformation or continuation? A critical analysis of the making of the post-2015 education agenda. Glob. Soc. Educ. doi:http://dx.doi.org/10.1080/ 14767724.2014 .959894$.

Erisman, H.M., 1991. Cuban development aid: South-South diversification and counterdependency politics. In: Erisman, H.M., Kirk, J.M. (Eds.), Cuban Foreign Policy Confronts a New International Order. Lynne Rienner, London, pp. 139-165.

Fägerlind, I., Saha, L.J., 1989. Education and National Development, 2nd ed. Butterworth, Oxford.

Fiddian-Qasmiyeh, E., 2015. South-South Educational Migration, Humanitarianism And Development. Views From The Caribbean, North Africa And The Middle East. Rouledge, Abingdon.

Freire, P., 1996[1970]. Pedagogy of the Oppressed, new revised edition. London, Penguin.

Giroux, H., 2014. Militarism's killing fields: from Gaza to Ferguson. Open Rev. Educ. Res. 1 (1), 8-19.

Graham-Brown, S., 1991. Education in the Developing World: Conflict and Crisis. Longman, London.

Gramsci, A., 1971. Selections from the Prison Notebooks (edited and translated by Q. Hoare and G. N. Smith). London: Lawrence \& Wishart. Grayson, G.W., 1985. The San José oil facility: South-South cooperation. Third World Q. 7 (2), 390-409.

Griffiths, T.G., Millei, Z., 2013a. Education in/for socialism: historical, current and future perspectives. Glob. Soc. Educ. 11 (2), 161-169. Logics of Socialist Education: Engaging with Crisis, Insecurity and Uncertainty. In: Griffiths, T.G., Millei, Z. (Eds.), Springer, Dordrecht. 
GRUN (Gobierno de Reconciliación y Unidad Nacional), 2012. Plan Nacional de Desarrollo Humano 2012-1016, preliminary version under national consultation, 8 November.

GRUN, 2014. Informe del Comandante Presidente Daniel al Pueblo y la Asamblea Nacional 2013. Managua, 28 May.

Hatzky, C., 2012. Cuba's educational mission in Africa: the example of Angola. In: Hickling-Hudson, A., Corona González, J., Preston, R. (Eds.), The Capacity to Share: A Study of Cuba's International Cooperation in Educational Development. Palgrave Macmillan, Houndmills, pp. 141-160.

Hickling-Hudson, A., Corona González, J., Lehr, S., Majoli Viani, M., 2012. The Cuban revolution and internationalism: structuring education and health. In: HicklingHudson, A., Corona González, J., Preston, R. (Eds.), The Capacity to Share: A Study of Cuba's International Cooperation in Educational Development. Palgrave Macmillan, Houndmills, pp. 13-34.

International Court of Justice, 1998. Nicaragua case (merits). In: Harris, D.J. (Ed.), Cases and Materials on International Law. Sweet and Maxwell, London, pp. 866-888.

Jules, T.D., Sá e Silva, M.M., 2008. How different disciplines have approached South-South cooperation and transfer. Soc. Int. Educ. J. 5 (1), 45-64.

King, K., 2014. China's engagement with the post-2015 development agenda: the case of education and training. Int. J. Educ. Dev. 39, 70-77.

Kane, L., 2001. Popular Education and Social Change in Latin America. Latin America Bureau, London.

Kozol, J., 1978. A new look at the literacy campaign in Cuba. Harvard Educ. Rev. 48 (3), 341-377.

Lambie, G., Alzugaray Treto, C. (Eds.), 2011. A new dawn? ALBA and the future of Caribbean and Latin American integration, International Journal of Cuban Studies, 3 (2/3, Special Issue).

Leal, E., 2013. Twenty-first century socialism: a political and pedagogical act. Some keys to understanding. In: Muhr, T. (Ed.), Counter-Globalization and Socialism in the 21st Century: The Bolivarian Alliance for the Peoples of Our America. Routledge, London, pp. 33-45.

Lind, A., 2008. Literacy For All: Making A Difference. UNESCO, Paris.

Lopes Cardozo, M.T.A., Strauss, J.A.S., 2013. From the local to the regional and back: Bolivia's politics of decolonising education in the context of the ALBA-TCP. In: uhr, T. (Ed.), Counter-Globalization and Socialism in the 21st Century: The Bolivarian Alliance for the Peoples of Our America. London, Routledge, pp. 203218. 
Martínez Pérez, F., 2012. Cuban higher education scholarships for international students: an overview. In: Hickling-Hudson, A., Corona González, J., Preston, R. (Eds.), The Capacity to Share: A Study of Cuba's International Cooperation in Educational Development. Palgrave Macmillan, Houndmills, pp. 73-82.

Mawdsley, E., 2012. From Recipients To Donors: Emerging Powers And The Changing Development Landscape. Zed, London.

McGrath, S., 2014. Editorial: education and the post-2015 international development goals. Int. J. Educ. Dev. 39, 1-3.

McLaren, P., 2000. Che Guevara, Paulo Freire, and the Pedagogy of Revolution. Rowman \& Littlefield, Lanham.

MERCOSUR, 2014. Informe de la Presidencia Pro Témpore Venezolana del MERCOSUR (PPTVEN), July 2013-July 2014, Acta No. 01/14, XLVI Ordinary Meeting of the Council of the Common Market, Caracas, 28 July 2014.

MINED (Ministerio de Educación), 2009. Informe Final. Campaña Nacional de Alfabetización "De Martí a Fidel” [Final report. National Literacy Campaign "From Martí to Fidel"]. Managua, MINED. MINED, 2011. Plan Estratégico de Educación 2011-2015. Managua, MINED. MINED, 2014. Educación de adultos, http://www.mined.gob.ni/index.php? option $=$ com_content $\&$ view $=$ article $\&$ id $=62 \% 3$ Aadultos $\&$ catid $=36 \%$ 3Amodalid\&Itemid=28 (accessed 3.11.11.).

MINED Juventud Sandinista, 2014. Método cubano YO, SI PUEDO, http://www. juventudalfabetizando.org.ni/yo_si_puedo.html (accessed 11.03.15.).

Motta, S.C., Cole, M., 2013a. Introduction: exploring the role of education and the pedagogical in pathways to twenty-first-century socialism in Latin America. In: Motta, S.C., Cole, M. (Eds.), Education and Social Change in Latin America. Palgrave Macmillan, New York, pp. 1-13.

Muhr, T., 2008. Nicaragua re-visited: from neoliberal 'ungovernability' to the Bolivarian Alternative for the Peoples of Our America (ALBA). Glob. Soc. Educ. 6 (2), 147-161.

Muhr, T., 2010a. Counter-hegemonic regionalism and higher education for all: Venezuela and the ALBA. Glob. Soc. Educ. 8 (1), 39-57.

Muhr, T., 2010b. TINA go home! ALBA and re-theorizing resistance to global capitalism. Cosmos History: J. Nat. Soc. Philos. 6 (2), 27-54.

Muhr, T., 2011. Conceptualising the ALBA-TCP: third generation regionalism and political economy. Int. J. Cuban Stud. 3 (2-3), 98-115. 
Muhr, T., 2012. (Re) constructing popular power in our America: Venezuela and the regionalisation of 'revolutionary democracy' in the ALBA-TCP space. Third World Q. 33 (2), 225-241. doi:http://dx.doi.org/10.1080/01436597.2012.666010.

Muhr, T., 2013a. Optimism reborn. Nicaragua's Participative Education Revolution, the Citizen Power development model and the construction of ' 21 st century socialism'. Glob. Soc. Educ. 11 (2), 276-295. http://dx.doi.org/10.1080/ 14767724.2013.782199.

Muhr, T., 2013b. Introduction: the enigma of socialism. In: Muhr, T. (Ed.), CounterGlobalization and Socialism in the 21st Century: The Bolivarian Alliance for the Peoples of Our America. Routledge, London, pp. 1-29.

Muhr, T., Verger, A., 2006. Venezuela: higher education for all. J. Crit. Educ. Policy Stud. 4 (1), 160-194.

Núnez Mosquera, P., 2010. Statement by Ambassador Pedro Núnez Mosquera, Permanent Representative of Cuba to the United Nations, during the 16th Session of the High-Level Committee on South-South Cooperation, New York, 4 February.

Radio Nacional de Venezuela, 2014. Programa Yo sí puedo supera los ocho millones de alfabetizados en el mundo, 31 October, http://www.rnv.gob.ve/index.php/ programa-yo-si-puedo-supera-los-ocho-millones-de-alfabetizados-en-todo- el-mundo (accessed 29.10.14.).

República Bolivariana de Venezuela, 2001. Líneas Generales del Plan de Desarrollo Económico y Social de la Nación 2001-2007. Caracas, República Bolivariana de Venezuela.

Robertson, S., Novelli, M., Dale, R., Tikly, L., Dachi, H., Alphonce, N., 2007. Globalisation, Education And Development: Ideas, Actors And Dynamics. DFID, London.

Sá e Silva, M.M., 2009. South-South cooperation: past and present.

Conceptualization and practice. In: Chisholm, L., Steiner-Khamsi, G. (Eds.), SouthSouth Cooperation in Education and Development. New York, Teachers College Press, pp. 39-59.

Sanín, M.C., 2012. Sistematizar para aprender: lecciones de nueve experiencias de cooperación Sur-Sur y triangular, Documento de Trabajo No. 1. Montevideo, Cooperación Sur-Sur.

Santos, B.D.S., Rodríguez-Garavito, C.A., 2005. Law, politics and the subaltern in counter-hegemonic globalization. In: Santos, B.D.S., Rodríguez-Garavito, C.A. (Eds.), Law and Globalization from Below. Cambridge University Press, Cambridge, pp. 1-26. Schwab, T., Sims, H., 1985. Relations with the communist states. In: Walker, T.W. (Ed.), Nicaragua: The First Five Years. Praeger, New York, pp. 447466. 
Steele, J., 2008. Yo, Sí Puedo: South-South educational collaboration in practice. Soc. Int. Educ. J. 5 (1), 29-43.

Steiner-Khamsi, G., 2007. International knowledge banks and the production of educational crises. EERJ Roundtable. Eur. Educ. Res. J. 6 (3), 285-292.

Szulanski, G., 1996. Exploring internal stickiness: impediments to the transfer of best practice within the firm. Strategic Manag. J. 17 (Special Issue), 27-43.

UNESCO, 2000. World Education Report 2000. The Right to Education: towards Education for All Throughout Life. UNESCO, Paris.

UNESCO, 2006. Study on the Effectiveness and Feasibility of the Literacy Training Method Yo, Sí Puedo, 175th Session, Paris, 175 EX/9.

UNESCO, 2006. Award of 2006 UNESCO Literacy Prizes, 3 November, http://portal. unesco.org/es/ev.phpURL_ID=35470\&URL_DO=DO_TOPIC\&URL_SECTION=201. html (accessed 29.10.14.).

UNESCO, OEI, INIDE, UNAN, IDEUCA, 2009. Informe. Comisión Nacional de Verificación: Verificación de la Tasa Nacional de Analfabetismo en Nicaragua 16/ 06/2009 [Report. National Commission for Verification: Verification of the Nicaraguan National Illiteracy Rate 16/06/2009]. Managua, UNESCO-Managua, OEI, INIDE, UNAN, IDEUCA. UNESCO, 2014a. EFA Global Monitoring Report /14. UNESCO, Paris.

UNESCO, 2014. En el país de Varela: Yo, sí puedo-education programme for young people and adults, http://www.unesco.org/uil/litbase/? menu=4\&programme $=93$ (accessed 2.07.14.).

Vanden, H.E., 1999. Democracy derailed: the 1990 elections and after. In: Prevost, G., Vanden, H.E. (Eds.), The Undermining of the Sandinista Revolution, Reprinted 1997 Edition with New Preface and Minor Alterations. St Martin's, New York, pp. 45-73.

Yaffe, H., 2013. Cuban socialism: inspiration to the ALBA-TCP. In: Muhr, T. (Ed.), Counter-Globalization and Socialism in the 21st Century: The Bolivarian Alliance for the Peoples of Our America. Routledge, London, pp. 101-118. 